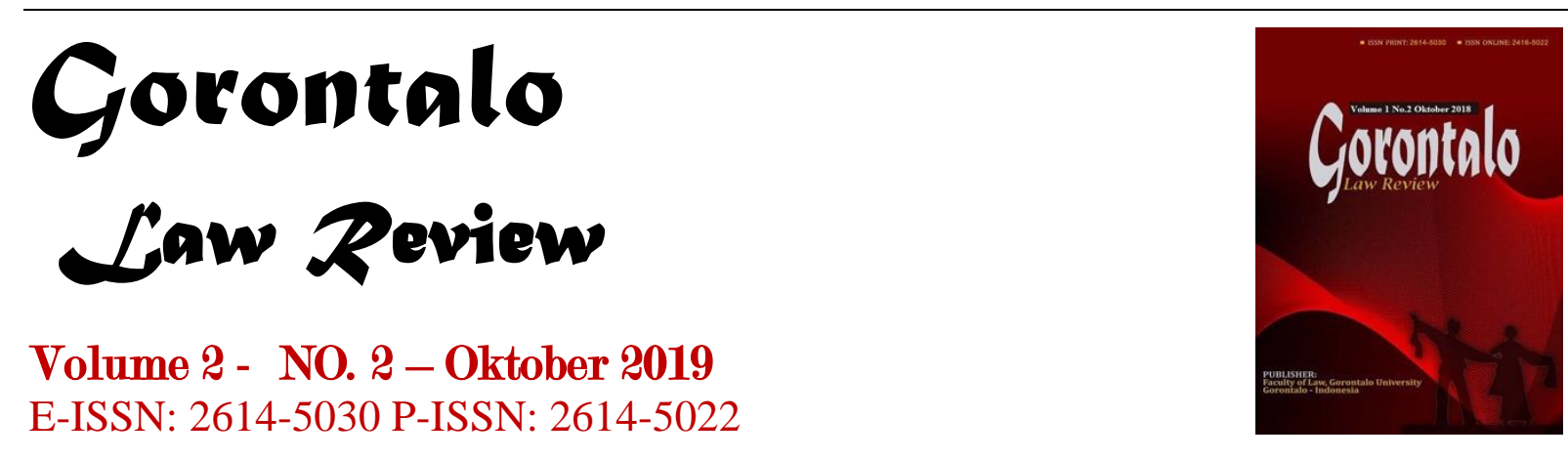

\title{
ASPEK HUKUM DALAM PENGELOLAAN WILAYAH PESISIR DALAM PERSPEKTIF OTONOMI DAERAH
}

\author{
Rahmat Datau \\ Fakultas Hukum, Universitas Muhammadiyah Gorontalo \\ rahmat.datau2014@gmail.com \\ Hairan \\ Fakultas Hukum, Universitas Mulawarman \\ harbot@yahoo.co.id
}

\begin{abstract}
Abstrak
Indonesia sebagai negara kepulauan yang memiliki garis pajang pantai sekitar 81.000 $\mathrm{km}$ memiliki potensi yang sangat besar untuk dikembangkan dan diberdayakan. Daerah sebagai wilayah yang berdasarkan Undang-undang memiliki kewenangan untuk mengelola sumber daya yang ada di wilayah masing-masing. Sesuai amanat dari Undang-undang Nomor 27 Tahun 2007 tentang Pengelolaan Wilayah Pesisir dan Pulau-pulau Kecil, memberikan kepada daerah untuk dapat melakukan pengelolaan wilayah pesisir karena potensi yang sangat besar. Selain potensi sumber daya alam juga potensi sumber daya manusia yang terlibat langsung dalam pengelolaan sumber daya wilayah pesisir dan berperan sebagai subyek bukan sebagai obyek. Pemerintah Daerah juga perlu memperhatikan potensi konflik dan hukum adat yang berlaku di kalangan masyarakat pesisir tersbeut sebagai bentuk akomodasi dari respon sosial masyarakat atas peraturan daerah yang dibuat.
\end{abstract}

\section{Kata Kunci : Hukum; Wilayah Pesisir; Otonomi Daerah}

\begin{abstract}
Indonesia as an archipelagic country which has coastline about $81,000 \mathrm{~km}$ and has enormous potential to be developed and empowered.Locality as regions based on the Law have the authority to manage resources in their respective regions. In accordance with mandate of Law Number 27 Year 2007 concerning Management of Coastal Areas and Small Islands, giving regions to be able to carry out management of coastal areas because of its enormous potential. In addition to the natural resources potential, there is also the human resources potential that directly involved in the coastal areas management and acting as subjects not as objects. Local governments also need to pay
\end{abstract}


attention to the conflict potential and customary law that prevails in these coastal communities as accommodation from the community social response to the made local regulations.

\section{Keywords: Law; Coastal Region,; and Regional Autonomy}

\section{PENDAHULUAN}

Indonesia merupakan negara kepulauan dengan jumlah pulau sekitar 17.508 dan garis pantai sepanjang $81.000 \mathrm{~km}$. (Gunalan; 2014; 1). Sudah saatnya harus diperhatikan pengelolaan wilayah pesisir yang sampai sekarang belum mendapat perhatian secara lebih dari Pemerintah.

Hampir seluruh wilayah pesisir di Indonesia memiliki potensi. Potensi itu bukan hanya dari sumber daya alam (SDA) (nature of resources) saja, tapi sumber daya manusia (SDM) (human of resources) yang selama ini sering terlewat untuk diperhatikan. Sumber daya alam (SDA) (nature of resources) di wilayah pesisir yang cukup besar, misalnya saja sumber daya alam (SDA) (nature of resources) yang tidak dapat diperbaharui seperti minyak dan gas bumi lebih banyak berada di wilayah pesisir atau pantai. Sumber daya alam (SDA) (nature of resources) yang dapat diperbaharui seperti kehutanan wilayah pesisir yang dapat diolah tanpa harus merusak seperti hutan bakau yang menjadi tempat ikan dan biota laut lainnya hidup dan berkembang. Sumber daya manusia (SDM) (human of resources) merupakan sumber daya sampai sekarang dianggap masih dalam keadaan "tidur" tanpa tersentuh oleh Pemerintah secara penuh dalam bentuk pembinaan.

Kondisi yang terbawa selama ini adalah masyarakat yang tinggal di wilayah pesisir merupakan kantong-kantong yang diidentikkan dengan kemiskinan. Masyarakat yang selalu dianggap sebagai orang yang hidup miskin. Sehingga dalam pemberlakuan hukum yang mengatur tentang wilayah pesisir yang sentralistik juga melibatkan masyarakat dalam penerapannya. Menurut Bodly dalam I Nyoman Nurjaya, mengatakan:"dalam konstruksi hukum yang sentralistik tidak tersedia ruang yang proporsional bagi partisipasi masyarakat yang sejati (genuine public participation) dalam pembangunan hukum, karena sejak awal telah ditanamkan pola hubungan yang bercorak sub-ordinasi antara pemerintah dengan masyarakat dalam kehidupan berbangsa dan bernegara; pemerintah menduduki posisi sebagai superior atau super-ordinasi antara pemerintah dengan masyarakat diposisikan sebagai komponen negara yang inferior atau sub-ordinasi. Implikasi yang muncul dari pola hubungan yang bercorak super-ordinasi dan sub-ordinasi adalah terjadinya viktimisasi masyarakat hukum adat dalam proses pembangunan nasional dan pembangunan hukum pada khususnya (victim of development). (I Nyoman Nurjaya: 2006:15)

Wilayah pesisir yang memiliki potensi, tetapi juga menyimpan banyak permasalahan yaitu kehidupan masyarakat yang belum tersentuh dengan tingkat kesejahteraan yang baik. Adanya Undang-undang Nomor 27 tahun 2007 tentang Pengelolaan Wilayah Pesisir dan Pulau-pulau Kecil, sebagaimana sekarang telah diubah dengan Undang-Undang Nomor 1 Tahun 2014 tentang Perubahan Atas Undang-Undang Nomor 27 Tahun 2007 Tentang Pengelolaan Wilayah Pesisir Dan Pulau-Pulau Kecil memberikan peluang yang besar kepada pemerintah Daerah untuk mengelola dan memberdayakan potensi tersebut.

Pengelolaan wilayah pesisir, maka banyak faktor yang perlu untuk disikapi secara arif oleh pengambil kebijakan oleh Kepala Daerah. Tentunya daerah-daerah yang memang memiliki daerah pesisir. Mengingat undang-undang tersebut belum ada aturan pelaksanaan, maka tentunya Pemerintah Daerah dapat menyikapi dengan membuat Peraturan Daerah. Khususnya pada Kabupaten/Kota yang memiliki kewenangan otonomi yang luas. (I Nyoman Nurjaya: 2006:20) 
Mengenai keterlibatan Pemerintah dan Pemerintah Daerah dalam pengelolaan wilayah pesisir sebagaimana diatur dalam Pasal 1 angka 1 Undang-Undang Nomor 1 Tahun 2014 tentang Perubahan Undang-undang Nomor 27 Tahun 2007 tentang Pengelolaan Wilayah Pesisir dan Pulau-pulau Kecil, menyebutkan:

"Pengelolaan Wilayah Pesisir dan Pulau-Pulau Kecil adalah suatu pengoordinasian perencanaan, pemanfaatan, pengawasan, dan pengendalian sumber daya pesisir dan pulau-pulau kecil yang dilakukan oleh Pemerintah dan Pemerintah Daerah, antarsektor, antara ekosistem darat dan laut, serta antara ilmu pengetahuan dan manajemen untuk meningkatkan kesejahteraan rakyat."

Seiring dengan sistem pemerintahan di Indonesia, maka sistem desentralisasi dilaksanakan oleh daerah melalui otonomi daerah. Pembagian daerah ini telah secara tegas disebutkan dalam Pasal 18 ayat (1) Undang-Undang Dasar Negara Republik Indonesia Tahun 1945, berbunyi:

Negara Kesatuan Republik Indonesia dibagi atas daerah-daerah provinsi dan daerah provinsi itu dibagi atas kabupaten dan kota, yang tiap-tiap provinsi, kabupaten, dan kota itu mempunyai pemerintahan daerah, yang diatur dengan undang-undang.

Sebagai mandatori dari ketentuan Pasal 18 ayat (1) Undang-Undang Dasar Negara Republik Indonesia Tahun 1945 tersebut, maka sekarang telah diberlakukan UndangUndang Nomor 23 Tahun 2014 tentang Pemerintahan Daerah. Sebagai daerah otonomi diberikan kewenangan untuk melaksanakan pengelolaan daerahnya, khususnya pada wilayah pesisir dan pulau-pulau kecil. Apalagi secara jelas kewenangan Pemerintah Daerah mengelola wilayah pesisir telah diatur dalam Undang-undang Nomor 32 Tahun 2004 tentang Pemerintah Daerah. (Baddu; 1998; 25). Demikian pula kewenangan itu sebagaimana dalam Undang-Undang Nomor 23 Tahun 2014 tentang Pemerintahan Daerah.

Pemerintah Daerah memiliki peluang dan wewenang yang besar dalam memberdayakan wilayah pesisir sebagai pola pengembangan baru. Hanya saja sampai saat ini peraturan pelaksanaan dari Undang-Undang Nomor 1 Tahun 2104 tentang Perubahan Undang-undang Nomor 27 Tahun 2007 tentang Pengelolaan Wilayah Pesisir dan Pulau-pulau Kecil berupa Peraturan Pemerintah. Oleh karena itu seharusnya Pemerintah Daerah dapat menyikapi dengan membuat Peraturan Daerah. (I Nyoman Nurjaya;2006;26)

Hanya dalam merumuskan dalam pengelolaan wilayah pesisir dan pulau-pulau kecil ini, juga daerah dibatasi dengan zonasi kewilayahan. Pembatasan kewenangan untuk wilayah pesisir ini dalam menjalankan otonomi daerah masih terbentuk batasan kewenangan dengan Pemerintah. Kesulitan dalam merumuskan muatan substansi regulasi berupa peraturan daerah dimaksud untuk memberikan kepastian hukum di daerah

Berlakunya Undang-Undang Nomor 23 Tahun 2014 tentang Pemerintahan Daerah justru tidak diberikan kewenangan dalam pengelolaan wilayah pesisir. Begitu kompleksitas permasalahan di wilayah pesisir dengan kewenangan sekarang berada di daerah provinsi. Pembatasan kewenangan ini membawa dampak yang luar biasa. Apalagi secara faktual hampir semua daerah pesisir secara universal yang terjadi penetapan status tanah wilayah pesisir, pengakuan hak-hak masyarakat adat wilayah pesisir, pembinaan dalam peningkatan kesejahteraan masyarakat pesisir, bahkan pada penyelesaian konflik masyarakat pesisir. Sehingga daerah Kabupaten/Kota yang memiliki wilayah pesisir kesulitan dalam menentukan regulasi daerah khusus untuk pengelolaan daerah pesisir, sementara faktanya masyarakat setiap saat berhubungan dengan pemerintah daerah Kabupaten/Kota

\section{METODE PENELITIAN}

Tulisan ini menggunakan metode yuridis normatif, atau penelitian kepustakaan, yaitu jenis penelitian yang bertumpu pada sumber data sekunder sebagai data 
rujukan utama yang terdiri dari bahan hukum primer, bahan hukum sekunder dan bahan hukum tersier. Bahanbahan tersebut disusun secara sitematis, dikaji, kemudian ditarik suatu kesimpulan dalam hubungannya dengan masalah yang diteliti. Pendekatan (Approach) yang dipergunakan adalah pendekatan UndangUndang (Statute approach) dalam hal ini Undang-Undang Nomor 1 Tahun 2014 tentang Perubahan Undang-Undang Nomor 27 Tahun 2007 tentang Pengelolaan Wilayah Pesisir dan Pulau-pulau Kecil dan Undang-Undang Nomor 23 Tahun 2014 tentang Pemerintahan Daerah.

\section{PEMBAHASAN}

\section{a. Peluang dan Dasar Hukum Pemerintah Daerah Dalam Mengelola Wilayah Pesisir.}

Setelah masa reformasi banyak perubahan yang terjadi dalam sistem Pemerintahan di Indonesia, khususnya pelaksanaan Pemerintah di Daerah. Saat berlakunya Undang-undang Nomor 5 Tahun 1974 tentang Pokok-Pokok Pemerintahan Di Daerah kewenangan Pemerintah Daerah sangat dibatasi. Terutama untuk daerah Kabupaten / Kota yang waktu itu disebut daerah Tingkat II tidak diberi kebebasan luas dalam mengelola wilayahnya. Meskipun secara pasti disebutkan dalam pasal 11 ayat (1) Undang-undang Nomor 5 Tahun 1974 menyebutkan:

"Titik berat Otonomi Daerah diletakkan pada Daerah Tingkat II".

Pelaksanaan Otonomi masih dianggap semu karena banyaknya kewenangan yang dibatasi oleh Pemerintah Pusat. Kewenangan yang dibatasi itu seperti hak untuk menentukan anggaran, kewenangan Pemerintah Daerah dalam mengelola dan hasilnya untuk daerahnya termasuk wilayah pesisir. Pembatasan itu tidak terasa dalam Undang-undang Nomor 5 Tahun 1974, tetapi secara politik dan hukum dilakukan pembatasan melalui Peraturan Pelaksanaan dibawahnya seperti Peraturan Pemerintah. (I Nyoman Nurjaya; 2006; 25)

Kemudian setelah 25 (dua puluh lima) tahun berlakunya Undang-undang Nomor 5 Tahu 1974 ini tidak banyak membawa perubahan dalam pelaksanaan otonomi daerah. Pada tahun 1999 setelah gerakan reformasi yang menuntut adanya perubahan-perubahan dalam pelaksanaan pemerintahan, penghapusan dwi fungsi ABRI, dan penegakan HAM. Salah satu yang menjadi perhatian publik adalah pelaksanaan Pemerintah di daerah dengan pelaksanaan Otonomi daerah melalui asas desentralisasi.

Oleh karena itu dibuat dan disahkan Undang-undang Nomor 22 Tahun 1999 tentang Pemerintahan Daerah. Undang-undang ini membuka seluas-luasnya dalam pelaksanaan Otonomi daerah bagi Pemerintah Daerah. Undang-undang ini hanya berumur sekitar 5 (lima) tahun saja lalu diubah dengan Undang-undang Nomor 32 Tahun 2004 tentang Pemerintahan Daerah. Undang-undang ini berlaku dan otonomi daerah bagi pemerintah daerah dalam menyelenggarakan Pemerintahan di Daerah sampai dengan tahun 2014. Tahun 2014 membawa perubahan besar dalam hal kewenangan antara Daerah Provinsi dan Kabupaten/Kota, yaitu disahkan dan diberlakukannya Undang-Undang Nomor 23 Tahun 2014 tentang Pemerintah Daerah. Undang-undang ini membawa perubahan dengan menarik kewenangan-kewenangan yang selama ini berada di Kabupaten/Kota diambil alih oleh provinsi, tertutama yang berkaitan dengan perizinan, tata kelola wilayah pesisir, wilayah administrasi.

Selain itu dengan adanya Undang-undang Nomor 33 Tahun 2004 tentang Perimbangan Keuangan memperjelas kewenangan daerah atas pendapatan yang diperoleh dari pengelolaan di daerahnya. Sebagaimana disebutkan dalam pasal 3 ayat (1) Undang-undang Nomor 33 Tahun 2004, menyebutkan:

"PAD bertujuan memberikan kewenangan kepada Pemerintah Daerah untuk mendanai pelaksanaan otonomi daerah sesuai dengan potensi Daerah sebagai perwujudan Desentralisasi” 
Secara teoritik kewenangan ini menurut Ateng Syafrudin berpendapat ada perbedaan antara pengertian kewenangan dan wewenang.(Ateng Syafrudin; 2000:22). Kita harus membedakan antara kewenangan (authority, gezag) dengan wewenang (competence, bevoegheid). Kewenangan adalah apa yang disebut kekuasaan formal, kekuasaan yang berasal dari kekuasaan yang diberikan oleh undang-undang, sedangkan wewenang hanya mengenai suatu "onderdeel" (bagian) tertentu saja dari kewenangan. Di dalam kewenangan terdapat wewenang-wewenang (rechtsbe voegdheden). Wewenang merupakan lingkup tindakan hukum publik, lingkup wewenang pemerintahan, tidak hanya meliputi wewenang membuat keputusan pemerintah (bestuur), tetapi meliputi wewenang dalam rangka pelaksanaan tugas, dan memberikan wewenang serta distribusi wewenang utamanya ditetapkan dalam peraturan perundang-undangan. Secara yuridis, pengertian wewenang adalah kemampuan yang diberikan oleh peraturan perundang-undangan untuk menimbulkan akibat-akibat hukum. (Indroharto; 1994:65) Pengertian wewenang menurut H.D. Stoud dalam Irfan Fachruddin adalah: "Bevoegheid wet kan worden omscrevenals het geheel van bestuurechttelijke bevoegdheden door publiekrechtelijke rechtssubjecten in het bestuurechttelijke rechtsverkeer". (wewenang dapat dijelaskan sebagai keseluruhan aturan-aturan yang berkenaan dengan perolehan dan penggunaan wewenang pemerintah oleh subjek hukum publik dalam hukum publik). (Irfan Fachruddin; 2004: 4).

Menurut Philipus Hardjon, wewenang juga dikenal pendelegasian. Pendelagasian wewenang ini, maka orang yang menerima delegasi disebut delegan, karena itu wewenang terdapat syarat-syarat yang harus dipenuhi, sebagai berikut :

a. Delegasi harus definitif, artinya delegans tidak dapat lagi menggunakan sendiri wewenang yang telah dilimpahkan itu.

b. Delegasi harus berdasarkan ketentuan perundang-undangan, artinya delegasi hanya dimungkinkan kalau ada ketentuan untuk itu dalam peraturan perundang-undangan.

c. Delegasi tidak kepada bawahan, artinya dalam hubungan hirarki kepegawaian, tidak diperkenankan adanya delegasi.

d. Kewajiban memberi keterangan (penjelasan); artinya delegans memberikan untuk meminta penjelasan tentang pelaksanaan wewenang tersebut.

e. Peraturan kebijakan (beleidsregel), artinya delegans memberikan instruksi (petunjuk) tentang penggunaan wewenang tersebut. (Philipus Hardjon; 1987: 187)

Delegasi sebagai bentuk dari pelimpahan wewenang, merupakan mandat yang diterima oleh delegans. Mandat sendiri menurut Kolsteren ${ }^{1}$ mengatakan berasal dari bahasa latin, "mandatum", kata kerjanya mandare,-atum yang berarti melimpahkan (overdragen), mempercayakan (toevertrouwen), memerintahkan (bevelen). (Kolsteren A;1990:85)

"Mandat" artinya pemberi beban (lastgever) dan berasal juga dari bahasa latin "mandans". Dalam pemberian kuasa berlaku asas yang maksudnya setiap pemberian kuasa harus didasarkan atas alasan yang sah (Mandatum nisi gratuitum nullum est).

Dengan demikian delegasi sebagai bentuk pelimpahan wewenang, tetapi tidaklah sama dengan mandat. Dimana mandat sebagai suatu pelimpahan kekuasaan yang melaksanakan tidak bertindak atas nama sendiri.

Terkait dengan kewenangan tersebut dengan dihubungkan pada kewenangan pengelolaan wilayah pesisir. Tentu saja peluang Pemerintah Daerah dalam mengelola wilayah pesisir sebagai suatu potensi. Berdasarkan Undang-undang Nomor 27 Tahun 2007 tentang Pengelolaan Wilayah Pesisir dan Pulau-pulau Kecil. Pengertian Wilayah Pesisir berdasarkan pasal 1 angka 2 menyebutkan :

1) $h \operatorname{lm} 85$ 
"Wilayah Pesisir adalah daerah peralihan antara Ekosistem darat dan laut yang dipengaruhi oleh perubahan di darat dan laut".

Sedangkan menurut, Aca Sugandhy, berdasarkan pendekatan secara ekologis, "Wilayah pesisir (coastal zone) mencakup semua wilayah yang merupakan kawasan pertemuan antara daratan dan lautan, ke arah darat meliputi bagian daratan baik kering maupun terendam air yang masih dipengaruhi oleh proses-proses yang berkaitan dengan laut atau sifat-sifat laut seperti pasang surut, angin laut dan perembesan air asin. Sedangkan ke arah laut kawasan pesisir mencakup bagian laut yang masih dipengaruhi oleh proses alami yang terjadi di darat seperti sedimentasi dan aliran air tawar, maupun yang disebabkan karena kegiatan manusia di darat seperti penggundulan hutan dan pencemaran". (Aca Sugandhy; 2000: 2). Wilayah pesisir merupakan kawasan yang memiliki karakteristik yang unik dan kompleks. Kompleksitas ditunjukkan oleh keberadaan berbagai pengguna dan berbagai entitas pengelola wilayah yang mempunyai kepentingan dan cara pandang yang berbeda mengenai pemanfaatan dan pengelolaan sumberdaya di wilayah pesisir. Dengan mempertimbangkan karakteristik tersebut, maka muncul suatu konsep pengelolaan sumberdaya pesisir terpadu (Integrated Coastal Zone Management). Pendekatan ini menjadi salah satu pendekatan andalan dalam mengelola berbagai potensi dan konflik sumberdaya yang ada di wilayah pesisir. (Nurul Yudo Suparman; 2016; 106)

Perlu dibedakan agar jangan sampai salah penafsiran bahwa semua darat yang berbatasan dengan air adalah wilayah pesisir. Melainkan wilayah yang dimaksud adalah wilayah darat yang berbatasan langsung dengan laut. Oleh Undang-undang Nomor 27 Tahun 2007 ini membutuhkan singkornisasi undang-undang dengan Undang-undang Nomor 23 Tahun 2014, maksudnya agar dalam pelaksanaan pengelolaan wilayah pesisir dapat secara terpadu dalam pelaksanaannya. Terpadu dalam arti yuridis melalui singkronisasi peraturan, juga terpadu dalam arti kelembagaan dalam garis koordinasi, termasuk juga dengan melibatkan masyarakat dalam pengelolaan wilayah pesisir. Hanya saja secara khusus terjadi membatasi wilayah administrasi dan kewenangan daerah untuk provinsi adalah 12 (dua belas) mil laut dan sepertiga saja untuk Kabupaten/Kota. Hal sama halnya diberikan pendapat oleh Wiryanta, yaitu:

Secara lebih khusus, Undang-undang Nomor 27 Tahun 2007 tentang Pengelolaan Wilayah Pesisir dan Pulau-Pulau Kecil mendefinisikan pengertian kawasan pesisir sebagai wilayah peralihan antara ekosistem darat dan laut yang saling berinteraksi, dimana ke arah 12 mil dari garis pantai untuk provinsi dan sepertiga dari wilayah laut itu untuk kabupaten/ kota ke arah darat batas administrasi kabupaten/kota. Dengan demikian, pembahasan mengenai kewenangan pengelolaan sumberdaya yang ada di kawasan pesisir oleh hanya dibatasi sejauh 12 mil laut dari garis pantai, selebihnya bukan lagi masuk dalam ranah pengelolaan kawasan pesisir. (Wiryanta; 2016;20)

Undang-Undang Nomor 23 Tahun 2014 tentang Pemerintahan Daerah diberikan batasan kewenangan dalam pengelolaan wilayah pesisir dan pulau-pulau kecil adalah sebagaimana dituangkan dalam Lampiran Y. Pembagian Urusan Bidang Perikanan dan Kelautan. Kewenangan itu dibagi, sebagai berikut:

1) Pemerintah, berwenang untuk:

a. Pengelolaan ruang laut di atas 12 mil dan strategis nasional;

b. Penerbitan izin pemanfaatan ruang laut nasional.

c. Penerbitan izin pemanfaatan jenis dan genetik (plasma nutfah) ikan antarnegara.

d. Penetapan jenis ikan yang dilindungi dan diatur perdagangannya secara internasional.

e. Penetapan kawasan konservasi.

f. Database pesisir dan pulau-pulau kecil 
2) Daerah Provinsi, berwenang untuk:

a. Pengelolaan ruang laut sampai dengan 12 mil di luar minyak dan gas bumi.

b. Penerbitan izin dan pemanfaatan ruang laut di bawah 12 mil di luar minyak dan gas bumi.

c. Pemberdayaan masyarakat pesisir dan pulau-pulau kecil

3) Daerah Kabupaten/Kota

Tidak ada kewenangan yang diberikan dalam menjalankan otonomi daerah.

Kabupaten/Kota tidak diberikan kewenangan dalam pengelolaan wilayah pesisir dan pulau-pulau kecil membawa dampak pada terhambatnya dalam tanggungjawab Pemerintah Daerah dalam meningkatkan kesejahteraan masyarakat. Peran Pemerintah Kabupaten/Kota selama ini memberikan kontribusi yang cukup besar bagi peningkatan kesejaheraan masyarakat pesisir. Peran Pemerintah Daerah Kabupaten/Kota dalam pemberian status alas hak (pedestal rights) atas tanah pesisir, pengakuan masyarakat adat pesisir. Terbukti telah memberikan manfaat kepada masyarakat. Sentralisasi kewenangan pengelolaan wilayah pesisir kepada provinsi perlu dilihat kemampuan dalam mengelolanya, yang selama ini segala sumber daya terdapat dan dilaksanakan Kabupaten/Kota. Padahal dalam pengelolaan yang baik dibutuhkan keseimbangan untuk mencapai hasil yang optimal. Menurut Efendi dalam Hasrijal Syandri, untuk mencapai optimalisasi ini diperlukan adanya tindakan pemeliharaan pada titik keseimbangan yang normal. Di sini sumberdaya alam memiliki peran sebagai modal pertumbuhan ekonomi (resource based economy) dan sekaligus sebagai penopang sistem kehidupan (life support system). Oleh karena itu sumberdaya alam senantiasa harus dikelola secara seimbang untuk menjamin keberlanjutan pembangunan nasional, dan untuk sebesar-besarnya kemakmuran rakyat. (Efendi; 2014; 108)

Provinsi dengan terdiri dari beberapa Kabupaten/Kota dalam melaksanakan otonomi daerah secara sendiri melaksanakan pengelolaan wilayah pesisir memerlukan sumber daya dan kemampuan. Adanya pelimpahan seperti delegasi kepada Kabupaten/Kota dalam pembinaan Provinsi tentu lebih ideal. Dalam hal pelimpahan wewenang pemerintahan melalui delegasi, menurut Philipus M. Hadjon sebagaimana dikutip oleh Juniarso Ridwan dan Achmad Sodik Sudrajat, terdapat syarat-syarat yang harus dipenuhi sebagai berikut:

1. Delegasi harus defenitif dan pemberi delegasi tidak dapat lagi menggunakan sendiri wewenang yang telah dilimpahkan itu;

2. Delegasi harus berdasarkan ketentuan peraturan perundang-undangan, artinya delegasi hanya dimungkinkan kalau ada ketentuan untuk itu dalam peraturan perundang-undangan;

3. Delegasi tidak kepada bawahan, artinya hubungan hierarki kepegawaian tidak diperkenankan adanya delegasi;

4. Kewajiban memberikan keterangan (penjelasan), artinya delegasi berwenang untuk meminta penjelasan tentang pelaksanaan wewenang tersebut;

5. Peraturan kebijakan, artinya delegan memberikan instruksi (petunjuk) tentang penggunaan wewenang tersebut. (Ali Marwan Hsb \& Evlyn Martha Julianthy; 2018; 5)

Bentuk pelimpahan kewenangan itu bertujuan untuk memberikan keringan Provinsi dan untuk memfungsikannya bersifat koordinatif dan pembinaan kabupaten/kota dalam pengelolaan wilayah pesisir. Undang-Undang Nomor 23 Tahun 2014 tentang Pemerintahan Daerah, kewenangan diberikan terkait dengan perikanan dan kelautan yaitu pengelolaan Tempat Pelelangan Ikan (TPI). Sementara kewenangan lain dapat dengan pola delegasi pada bidang tertentu. Ada kewenangan terkait penetapan hak ulayat masyarakat hukum adat wilayah pesisir. 
Menurut Nugroho dan Dahuri dalam Kurniawati Hapsari Ekosafitri, alasan pengelolaan wilayah pesisir dan lautan harus memenuhi kaidah keberlanjutan (sustainability) adalah sebagai berikut:

1) komponen hayati dan non hayati dalam wilayah pesisir membentuk suatu ekosistem yang kompleks hasil dari ragam biofisik (ekologis) yang rentan terhadap perubahan yang disebabkan kegiatan manusia maupun bencana alam;

2) wilayah pesisir mempunyai ragam ekologi maupun keuntungan lokasi (location advantage) biasanya ditemukan beragam pemanfaatan untuk keperluan pembangunan seperti budi daya tambak, perikanan tangkap, pariwisata serta industri atau permukiman;

3) wilayah pesisir pada umumnya terdapat lebih dari satu kelompok masyarakat (orang) yang mempunyai keterampilan atau keahlian dan kesenangan (preference) bekerja yang berbeda sebagai nelayan, petani tambak, petani rumput laut, pendamping pariwisata, serta bekerja di sektor industri dan kerajinan;

4) secara ekologis dan ekonomis, pemanfatan pesisir secara monokultur (single use) sangat rentan terhadap perubahan internal maupun eksternal yang menjurus pada kegagalan usaha, sebagai contoh pembukaan hutan mangrove menjadi tambak udang;

5) wilayah pesisir dan laut umumnya merupakan sumber daya milik bersama (common property resources) yang dapat dimanfaatkan oleh semua orang. Oleh karena itu pemanfaatan wilayah pesisir dan laut memerlukan perencanaan dan pengelolaan secara serius dari pemerintah, masyarakat, dan stakeholder yang berkepentingan di dalamnya. (Kurniawati Hapsari Ekosafitri ed all; 2017;148),

Dari kewenangan tersebut, maka tentunya di daerah wajib dibentuk lembaga berupa Perangkat Daerah yang diberikan kewengan untuk melaksanakan kewenangan itu (Leading Sector). Pengaturan wajib disertai kelembagaan dalam manajemen yang baik untuk bisa melaksanakan pengaturan tersebut. Menurut Neilsen dalam Rahmat Syafa'at, mengatakan: Co-management, yaitu suatu bentuk perangkat kelembagaan dan hukum antara pemerintah dan kelompok masyarakat pengguna untuk mengelola secara efektif dan berkelanjutan suatu sumber daya". (Rahmad Syafa'at; 2008:163)

Penulis berpendapat bahwa wilayah pesisir dengan kompleksitas masalah, mulai penguasaan tanah oleh masyarakat, hak-hak masyarakat adat pesisir, sistem tata kelola perekonomian pesisir, pemberdayaan masyarakat pesisir dalam peranan budaya. Perlu keseimbangan kewenangan pengelolaan karena berhubungan dengan kemampuan sumber daya, dan kompleksitas wilayah pesisir dan pulau-pulau kecil.

Peluang daerah yang besar itu dapat disikapi dengan Peraturan Daerah yang mengatur tentang pengelolaan wilayah pesisir sebagai implemntasi dari Undangundang Nomor 27 Tahun 2007 tentang Pengelolaan Wilayah Pesisir dan Pulau-pulau Kecil. Peluang ini dengan peranandari Pemerintah Daerah yang terdiri dari Pemerintah Daerah dan DPRD, khususnya pada tingkat Kabupaten/Kota yang memiliki otonomi daerah, bukan pada tingkat provinsi, karena provinsi selain otonomi yang membawahi Kabupaten/Kota juga sebagai perpanjangan tangan dari Pemerintah Pusat melalui Dekonstrasi an tugas pembantuan.

Sebelumnya peraturan yang dirancang dan dibuat Pemerintah Daerah itu harus memikirkan terhadap dampak hukum atas ketidakharmonisan peraturan tersebut. Ada 4 (empat) dampak positif (benefit) dan dampak negatif (cost), dan dampak yang timbul, yaitu :

1) Diffused Costs, Diffused Benefit $(D C / D B)$, hasil harmonisasi dapat menimbulkan beban yang harus dipikul oleh rakyat (Diffused Costs) dan memberi manfaat yang dapat dinikmati oleh rakyat banyak Diffused Benefit. Hal ini adil apabila rakyat banyak menikmati manfaat dari hasil harmonisasi adalah sama dengan rakyat 
banyak yang harus memilkul beban yang ditimbulkan oleh harmonisasi. (Coastal Resources Management Project; 2005:140)

2) Diffused Costs, Concentrated Benefit ( $D C / C B)$, hasil harmonisasi ini menimbulkan ketidakadilan. Hal ini disebabkan oleh karena beban yang ditimbulkan oleh harmonisasi harus dipikul oleh rakyat banyak (Diffused Costs), sedangkan manfaatnya dinikmati oleh segelintir orang atau kelompok saja (Concentrated Benefit). (Coastal Resources Management Project; 2005:141)

3) Concentrated Costs, Diffused Benefit (CC/DB), hasil harmonisasi dapat menghasilkan manfaat untuk rakyat banyak (Diffused Benefit), dengan beban yang timbul dari kegiatan harmonisasi ditanggung oleh segelintir kelompok saja (Concentrated Costs). (Coastal Resources Management Project; 2005:141)

4) Concentrated Costs, Concentrated Benefit $(C C / C B)$, hasil harmonisasi dapat menimbulkan beban yang harus dipikul oleh sekompok rakyat (Concentrated Costs) dan memberi manfaat yang dapat dinikmati oleh sekelompok rakyat (Concentrated Benefit). Hal ini adil apabila sekelompok rakyat yang menikmati manfaat dari hasil harmonisasi adalah sama dengan sekelompok rakyat yang harus memikul beban yang ditimbulkan oleh harmonisasi. (Coastal Resources Management Project; 2005:141)

Peluang ini memberi kesempatan kepada daerah melalui Pemeritah Daerah untuk dapat menyusun Peraturan Daerah sebagai payung hukum (Umberella Law) untuk menyikapi Undang-undang Nomor 27 tahun 2007 pada tingkat daerah dalam pelaksanaan secara teknis di daerah pesisir. Tentunya dengan memperhatikan halhal yang dapat menguntungkan dan merugikan kehdupan masyarakat. Karena tujuan terakhir di buatnya peraturan adalah untuk meningkatkan kesejahteraan, bukan menambah belenggu rakyat pesisir menjadi terikat oleh aturan yang bermuatan kewajiban yang harus ditaati.

\section{b. Tahapan Pengelolaan Wilayah Pesisir Oleh Pemerintah Daerah}

Pengelolaan wilayah pesisir tentu saja ada beberapa tahapan. Tahapan tersebut juga dipertimbangkan mengenai rencara strategis dari pengelolaan wilayah pesisir itu. Rencana strategis pengelolaan wilayah pesisir ini melibatkan berbagai sektor atau bidang. Artinya tidak dapat dilakukan dengan hanya memperhatikan wilayah pesisir semata. Sektor atau bidang yang menjadi kesatuan yang secara bersama-sama diperhatikan dalam pengelolaan wilayah pesisir seperti bidang ekonomi, sosial masyarakat setempat, hukum adat, lingkungan setempat, termasuk secara geografis tempat dimana masyarakat itu berada di wilayah pesisir. Oleh karena itu pengelolaan wilayah pesisir dilakukan secara terpadu.

Dalam penerapan Undang-undang Nomor 27 Tahun 2007, maka yang perlu diperhatikan daerah dalam melakukan pengelolaan wilayah pesisir yang selanjutnya tidak diatur dalam Peraturan Pemerintah. Oleh karena itu sesuai amanat Undangundang Nomor 27 Tahun 2007 tersebut terdapat beberapa tahapan sebelum pengelolaan wilayah pesisir di laksanakan sebagai suatu aktivitas pembangunan. Pengelolaan wilayah pesisir yang dibatasi 12 (dua belas) mil dari laut kearah darat ketika air laut dalam keadaan pasang. Adapun tahapan yang dapat disikapi oleh Pemerintah Daerah sehingga dapat dijabarkan dalam Peraturan Daerah yang tentunya tidak bertentangan dengan Peraturan yang lebih tinggi, yaitu Undangundang, sebagai berikut:

1. Perencanaan, Perencanaan dilakukan melalui pendekatan Pengelolaan Wilayah Pesisir dan Pulau-Pulau Kecil terpadu (Integrated CoastalManagement) yang mengintegrasikan berbagai perencanaan yang disusun oleh sektor dan daerah sehingga terjadi keharmonisan dan saling penguatan pemanfaatannya. Perencanaan wilayah pesisir dan pulau-pulau kecil dibagi ke dalam empat tahapan: (i) rencana strategis; (ii) rencana zonasi; (iii) rencana pengelolaan; dan (iv) rencana aksi. 
2. Pengelolaan, Pengelolaan wilayah pesisir dan pulau-pulau kecil mencakup tahapan kebijakan pengaturan antara lain pemanfaatan dan pengusahaan perairan pesisir dan pulau-pulau kecil dilaksanakan melalui pemberian izin pemanfaatan dan Hak Pengusahaan Perairan Pesisir (HP-3). Izin pemanfaatan diberikan sesuai dengan peraturan perundang-undangan dan kewenangan masing-masing instansi terkait.

3. Pengawasan dan Pengendalian, Pengawasan dan pengendalian dilakukan untuk:

a. mengetahui adanya penyimpangan pelaksanaan rencana strategis, rencana zonasi, rencana pengelolaan, serta implikasi penyimpangan tersebut terhadap perubahan kualitas ekosistem pesisir;

b. mendorong agar pemanfaatan sumber daya di wilayah pesisir dan pulau-pulau kecil sesuai dengan rencana pengelolaan wilayah pesisirnya;

c. memberikan sanksi terhadap pelanggar, baik berupa sanksi administrasi seperti pembatalan izin atau pencabutan hak, sanksi perdata seperti pengenaan denda atau ganti rugi; maupun sanksi pidana berupa penahanan ataupun kurungan.

Pengaturan tata ruang wilayah pesisir dalam Undang-undang Nomor 27 Tahun 2007 masuk dalam Rencana Zonasi Wilayah Pesisir dan Pulau-Pulau Kecil (RZWP-3K) pemerintah Provinsi dan/atau pemerintah Kabupaten/Kota. RZWP-3-K diserasikan, diseleraskan dan diseimbangkan dengan Rencana Tata Ruang Wilayah (RTRW) pemerintah Provinsi atau pemerintah Kabupaten/Kota dengan mempertimbangkan hal berikut:

1. Keserasian, keselarasan, dan keseimbangan dengan daya dukung ekosistem, fungsi pemanfaatan dan fungsi perlindungan, dimensi ruang dan waktu, dimensi teknologi dan sosial budaya, serta fungsi pertahanan dan keamanan.

2. Keterpaduan pemanfaatan berbagai jenis sumber daya, fungsi, estetika lingkungan, dan kualitas lahan pesisir.

3. Kewajiban untuk mengalokasikan ruang dan akses masyarakat dalam pemanfaatan wilayah pesisir dan pulau-pulau kecil yang mempunyai fungsi sosial dan ekonomi.

Dari tahapan yang telah di uraikan diatas sebagaimana diamanatkan Undangundang Nomor 27 Tahun 2007, maka tidak kalah pentingnya adalah dengan memperhatikan tata ruang wilayah sebelumnya dengan tujuan agar pelaksanaan pemberdayaan tersebut telah dianggap melibatkan masyarakat sebagai poros utamanya sebagai penggerak. Sedangkan kondisi fisik lainnya termasuk alam sekitar khususnya wilayah pesisir, dan dipengaruhi oleh alam dan lingkungan sekitarnya. Sehingga dalam pelaksanaannya pengelolaan wilayah pesisir dibagi dalam zona-zona. Pembagian zona sangat dipengaruhi oleh kondisi alam di pesisir. Pengelolaan wilayah pesisir pada umumnya seperti disampaikan oleh Dyah Marganingrum, membagi zonazona tersebut dalam beberapa zone, yaitu mintakan preservasi, konservasi dan pemanfaatan. (Dyah Marganingrum ; 2007:66)

\section{c. Perlunya Daerah Memperhatikan Konflik Dalam Mengelola Wilayah Pesisir}

Peran Pemerintah sangat penting dalam melakukan kegiatan pembangunan yang berbasis pada pemberdayaan masyarakat secara aktif. Suatu wilayah yang akan dike.mbangkan kemajuannya harus memperhatikan pada kondisi sosial masyarakat setempat. Konflik bisa terjadi karena adanya beberapa sumber penyebab. Sumbersumber konflik menurut I Nyoman Nurjaya adalah :

1. Penguasaan, pemanfaatan dan distribusi sumber daya alam yang menjadi pendukung kehidupan manusia (natural resource control and distribution)

2. Ekspansi batas wilayah kehidupan suatu kelompok masyarakat (teritoriality expantion)

3. Kegiatan ekonomi masyarakat (economic activities), dan

4. Kepadataan penduduk (density of population). (I Nyoman Nurjaya: 2006; 40) 
Apalagi pengelolaan wilayah pesisir yang tentu saja melibatkan peran aktif dari masyarakat setempat. Bahwa masyarakat yang bertempat tinggal di pesisir memiliki karakteristik yang khas. Kekhasan masyarakat wilayah pesisir temprament emosi yang sangat tinggi dibandingkan dengan masyarakat yang bukan berada di wilayah pesisir. Hal tersebut bisa dipengaruhi oleh alam yang memang keras bagi mereka dalam memenuhi kebutuhan hidupnya, yaitu dengan pergi ke laut untuk mencari ikan. Ditambah lagi dengan sosial budaya yang memang sudah tercipta secara kodrati.

Sehingga dalam mengelola wilayah pesisir Pemerintah Daerah tidak dapat memaksakan dengan karakter yang lain, atau dengan mengenaralisasi kehidupan mereka menjadi global. Justru adanya perbedaan sebagai wujud dari pluralis yang beraneka ragam itu merupakan suatu sumber daya yang tidak ternilai harganya dalam mengelola wilayah pesisir. Oleh karena itu perbedaan menurut Ahmad Baso, mengatakan:

"Paham kemajemukan masyarakat atau pluralisme tidak cukup hanya dengan sikap mengakui dan menerima kenyataan masyarakat yang majemuk, tetapi harus disertai dengan sikap yang tulus untuk menerima kenyataan kemajemukan itu sebagai nilai yang positif, sebagai rahmat Tuhan kepada manusia, karena akan memperkaya pertumbuhan budaya melalui interaksi yang dinamis dan melalui pertukaran silang budaya yang beraneka ragam. Pluralisme adalah suatu perangkat untuk mendrong pengkayaan budaya bangsa. Budaya Indonesia, atau "keindonesiaan", tidak lain adalah hasil interaksi yang kaya (resourceful) dan dinamis antara pelaku budaya yang beraneka ragam itu dalam suatu melting pot yang efektif." (Ahmad Baso: 1999 ; 23)

Kemajemukan masyarakat di wilayah pesisir bagi Pemerintah Daerah sebagai dasar dalam menyerap aspirasi yang dituangkan dalam Peraturan Daerah. Peraturan Daerah sebagai bentuk dari respon dari tuntutan dan kebutuhan masyarakat yang perlu diatur dalam pengelolaan wilayah pesisir. Oleh karena itu pemetaan konflik dalam pengelolaan wilayah pesisir terhadap masyarakatnya juga menyerap hukum adat yang berlaku di kalangan masyarakat setempat, sebagai bentuk aturan yang selama ini ditaati dan diyakini kebenarannya oleh masyarakat.

Wilayah pesisir yang didiami masyarakat yang umumnya sebagai nelayan dan petani. Menunjukkan kerentanan terjadi konflik. Konflik yang dapat terjadi, yaitu:

1. Terjadi kerentanan konflik karena kemiskinan. Kemiskinan di Indonesia didominasi pada bagian wilayah pesisir.

2. Kerentanan konflik karena penguasaan sumber daya laut seperti wilayah tangkapan ikan atau budidaya perikanan.

3. Ketentanan konflik pada penguasaan sistem perekonomian atas penguasaan hasil tangkapan perikanan bebas dan budidaya.

4. Kerentanan terjadinya konflik melalui penetapan batas wilayah administrasi daerah.

Pemetaan potensi konflik wilayah pesisir, perlu dengan meningkatkan peran serta masyarakat. Peran serta masyarakat pesisir untuk menciptakan kesejahteraan, sebagai kunci dalam meminimalisir terjadinya konflik. Menurut Anak Agung Istri Ari Atu Dewi, disampaikan bahwa, hal ini sangat kental dipengaruhi oleh potensi, karakteristik dan nilai-nilai kearifan lokal masyarakat setempat. Dengan demikian pengelolaan wiayah pesisir yang dilakukan berbasis masyarakat tentunya berujung pada tercapainya kesejahteraan masyarakat pesisir, terutama mengurangi angka kemiskinan pada masyarakat pesisir. Di sisi lain, peran pemerintah dalam hal ini adalah bahwa pemerintah wajib memberikan perlindungan dan pemenuhan atas kesejahteraan masyarakat khususnya pemberantasan kemiskinan. Namun secara realita, kehidupan masyarakat pesisir masih hidup dalam kemiskinan. (Anak Agung Istri Ari Atu Dewi; 2018; 166) 
Perhatian lebih untuk wilayah pesisir yang selama ini masih kurang dibandingkan dengan daerah daratan lainnya. Sering kali dalam pelaksanaan program pemerintah daerah kurang mengakomodir kepentingan masyarakat. Perencanaan yang merata termasuk wilayah pesisir termasuk dalam penataan ruang dalam rencana, tentu dapat mempercepat dan mengurangi potensi terjadinya konflik. Seiring dengan pendapat Mujio, Pemetaan konflik merupakan suatu teknik yang digunakan. untuk menggambarkan secara grafis, menghubungkan pihakpihak dengan masalah dan dengan pihak-pihak lainnya.Pemetaan potensi konflik pemanfaatan ruang pesisir yang akan dikaji merupakan bagian dari salah satu analisis yang dilakukan dalam penelitian mengenai Model Rencana Zonasi Kawasan Pesisir dengan Pendekatan Keterkaitan Spasial (Spatial Connectivity) antara daratan dan perairan pesisir. (Mujio ed all; 2016; 139)

Menurut Mahfud Effendy, bahwa pembangunan di wilayah pesisir yang merupakan proses perubahan untuk meningkatkan taraf hidup masyarakat, tidak terlepas dari aktifitas pemanfaatan ruang dan sumberdaya pesisir juga aktifitas pemanfaatan jasa asimilasi lingkungan pesisir. Aktifitas-aktifitas ini sering melakukan perubahan-perubahan pada sumberdaya alam. Perubahan-perubahan yang dilakukan tentunya akan memberikan pengaruh pada lingkungan hidup. Makin tinggi laju pembangunan, makin tinggi pula tingkat pemanfaatan ruang, sumberdaya dan jasa asimilasi dan makin besar pula perubahan yang terjadi pada lingkungan hidup yang mengancam kapasitas keberlanjutannya (sustainable capacity). (Mahfud Effendy; 2009; $83-84$ )

\section{KESIMPULAN}

a. Pengelolaan wilayah pesisir dan pulau-pulau kecil terkait dengan ootonomi daerah sebagai pemegang kewenangan untuk mengelola daerahnya menjadi sangat terbatas. Undang-undang Nomor 27 Tahun 2007 ini membutuhkan singkornisasi undang-undang dengan Undang-undang Nomor 23 Tahun 2014, maksudnya agar dalam pelaksanaan pengelolaan wilayah pesisir dapat secara terpadu dalam pelaksanaannya.

b. Rencara strategis dari pengelolaan wilayah pesisir itu. Rencana strategis pengelolaan wilayah pesisir ini melibatkan berbagai sektor atau bidang. Artinya tidak dapat dilakukan dengan hanya memperhatikan wilayah pesisir semata.

c. Wilayah Pesisir dan Pulau-pulau kecil cukup rentan terjadinya konflik sosial. Dibutuhkan program perencanaan, pelaksanaan, pengawasan, dan pembinaan kepada masyarakat karena ketentanan dilatarbelakangi kemiskinan, penguasaan ekonomi pasar, sumber daya laut, dan tapal batas wilayah administrasi sebagai akibat penetapan wilayah.

\section{DAFTAR PUSTAKA}

\section{Buku}

Aca Sugandhy, Penataan Kawasan Pesisir Yang Berkelanjutan, Makalah Seminar Nasional Pengembangan Wilayah dan Pengelolaan Sumber Daya Alam di Kawasan Pesisir dalam rangka Penataan Ruang yang Berkelanjutan, (Bandung, FH UNPAD, 2000)

Ahmad Baso, Civil Society Versus Masyarakat Madani: Akeologi Pemikiran "Civil Society" dalam Islam Indonesia, (Bandung : Pustaka Hidayah ; 1999)

Ateng Syafrudin, Menuju Penyelenggaraan Pemerintahan Negara yang Bersih dan Bertanggung Jawab, Jurnal Pro Justisia Edisi IV,( Bandung, Universitas Parahyangan, 2000)

Badu, 1998, Pesisir, Jakarta, Armico

Dyah Marganingrum, Tinjauan Karakteristik Wilayah Pantai Utara dan Pantai Selatan Jawa Barat dalam Rangka Pengalolaan Kawasan Pesisir Terpadu, Sumber Daya Air di Wilayah Pesisir \& Pulau-Pulau Kecil di Indonesia editor Robert M. Delinom (Ed). (Jakarta : LIPI Press, 2007) 
I Nyoman Nurjaya, Pengelolaan Sumber Daya Alam Dalam Perspektif Antropologi Hukum, (Malang; Program Magister Ilmu Hukum, Arena Hukum Majalah Fakultas Hukum Unibraw, dan Penerbit UNM Press, 2006)

Indroharto, Asas-Asas Umum Pemerintahan yang Baik, (Bandung: Citra Aditya Bakti, 1994)

Irfan Fachruddin, Pengawasan Peradilan Administrasi terhadap Tindakan Pemerintah, (Bandung: Alumni, 2004)

Kolsteren A, Prisma Vreemde Woordenbock, cet.IV, (Het SpectrumN.V) Utrecht, hlm 198. Dikutip dalam Suwoto Mulyosudarmo, Kekuasaan dan Tanggung Jawab Presiden Republik Indonesia, Disertasi Fakultas Pascasarjana UNAIR, (Surabaya, 1990),

Pengembangan Wilayah Pesisir Melalui Pengelolaan Sumberdaya Perikanan Berbasis Masyarakat Di Kabupaten Gorontalo Utara, Gunalan, Universitas Gadjah Mada, 2014 Diunduh dari http://etd.repository.ugm.ac.id/

Philipus.M. Hardjon, Perlindungan Hukum Bagi Rakyat Indonesia, Sebuah Study Tentang Prinsip-prinsipnya, Penanganannya oleh Pengadilan Dalam Lingkungan Peradilan Umum dan Pembentukan Peradilan Administrasi Negara, (Surabaya, Bina Ilmu, 1987)

Rahmad Syafa'at, et all; Negara, Masyarakat Adat dan Kearifan Lokal, (Malang; InTrans Publishing, 2008)

Kementerian Perencanaan Pembangunan Nasional/Badan Perencanaan Pembangunan Nasional, Departemen Kelautan dan Perikanan, Departemen Hukum dan Hak Asasi Manusia bekerjasama dengan Coastal Resources Management Project), Buku Narasi, Menuju Harmonisasi Sistem Hukum Sebagai Pilar Pengelolaan Wilayah Pesisir Indonesia, (Jakarta ; 2005)

\section{Jurnal}

Anak Agung Istri Ari Atu Dewi, Model Pengelolaan Wilayah Pesisir Berbasis Masyarakat: Community Based Development (Community Based Development: Community-Based Coastal Area Management Model), Jurnal Penelitian Hukum DE JURE, ISSN 1410-5632 Vol. 18 No. 2, Juni 2018

Ali Marwan Hsb \& Evlyn Martha Julianthy; Pelaksanaan Kewenangan Atribusi Pemerintahan Daerah Berdasarkan Undang-Undang Nomor 23 Tahun 2014 Tentang Pemerintahan Daerah, Jurnal LEGISLASI INDONESIA Vol 15 No.2 Juli 2018.

Efendi; Kewenangan Pengelolaan Sumber Daya Alam Pada Era Otonomi Khusus Di Aceh, Yustisia Vol. 3 No.2 Mei - Agustus 2014

Mahfud Effendy, Pengelolaan Wilayah Pesisir Secara Terpadu: Solusi Pemanfaatan Ruang, Pemanfaatan Sumberdaya Dan Pemanfaatan Kapasitas Asimilasi Wilayah Pesisir Yang Optimal Dan Berkelanjutan, Jurnal KELAUTAN, Volume 2, No.1 April 2009.

Mujio, Luky Adrianto, Kadarwan Soewardi dan Yusli Wardiatno, Analisis Potensi Konflik Pemanfaatan Ruang Kawasan Pesisir: Integrasi Rencana Tata Ruang Darat Dan Perairan Pesisir (Analysis of Potential Spatial Conflicts at Coastal and Marine Zones: Integration of the Spatial Planning of Land and Coastal Water), Sodality: Jurnal Sosiologi Pedesaan , Agustus 2016

Kurniawati Hapsari Ekosafitri1, Ernan Rustiadi \& Fredinan Yulianda, Pengembangan Wilayah Pesisir Pantai Utara Jawa Tengah Berdasarkan Infrastruktur Daerah: Studi Kasus Kabupaten Jepara (Development of Central Java's Nothern Coast Based on Local Infrastructure: Case Study of Jepara Regency), Journal of Regional and Rural Development Planning Juni 2017, 1 (2) 
E-ISSN: 2614-5030-5030 P-ISSN: 2614-5022

Volume 2 No. 2 - Oktober 2019

Nurul Yudo Suparman, Kajian Yuridis Kewenangan Pemerintah Daerah Dalam Mengelola Wilayah Pesisir Di Kota Bitung, Jurnal Lex et Societatis, Vol. IV/No. 3/Mar/2016.

Wiryanta, Integrasi Penataan Pertanahan Dalam Kerangka "Penataan Wilayah Pesisir dan Lahan Atas Terpadu", bhumi, Jurnal Agraria dan Pertanahan, Yogyakarta, Mei 2016, Vol 2. 